\title{
The Effectiveness of Inservice Professional Development of English Language Teachers by Teaching Associates and Its Impact on L2 Learning in Foundation Schools
}

\author{
Zarqa Feroz \\ English Language Development Centre, Mehran University of Engineering and Technology. \\ Jamshoro, Sindh, Pakistan \\ Shabana Sartaj \\ Sindh Agriculture University Tandojam
}

\begin{abstract}
This study was intended to investigate teacher's professional development initiative by an educational foundation in free of cost foundation schools. The appointment of teaching associates is done by the educational foundation funded by Government of Sindh as English language specialists for English language teachers to enhance their knowledge, improvement in teaching practices, learning different language teaching methods and strategies and developing their overall teaching skills. For this purpose data was collected through semi-structured interviews of English language teachers and Teaching Associates to gain knowledge of their perceptions regarding effectiveness of in-service professional development. Observations of language teachers were also conducted to deeply investigate the extent to which Teaching Associates have been successful to achieve objectives set for English language teaching by foundation and the extent to which in-service professional development by Teaching Associates has been implemented in English language classrooms of foundation schools. The data obtained by semi-structured interviews has been analyzed thematically. Whereas, data obtained from observations has been analyzed through SPSS Version 26. The results showed that the in-service professional development has put positive effects on capacity building of teachers. Majority of teachers have been benefited in terms of Instructional planning, proper lecture delivery, Usage of relevant methods and strategies, Error analysis and error correction in language classes along with usage of consolidation and assessment techniques to improve their performance as well as the performance of language learners. The study recommended proper consideration towards usage of English language in the language classes and attention towards conceptual clarity. Thus, TAs need to work more on their planning for professional development of language teachers in foundation schools.
\end{abstract}

Keywords: Professional development, Teacher education, Model classes, Training sessions, class observations, Foundation schools.

DOI: $10.7176 /$ RHSS/10-17-03

Publication date:October $31^{\text {st }} 2020$

\section{Introduction}

Teachers' professional development is wide and far reaching. Other than pre teaching programs for teachers, it is intended to be engaged with different network projects and expansion exercises, grown-up training and non-formal training projects, proficiency and advancement exercises. Teachers training lands at all degrees of preparing, to be explicit Early, Primary, Elementary, Secondary, Higher Secondary and even at the high level Education. The necessities and prerequisites of understudies and teaching fluctuate at every level. Thus, level appropriate teacher education is fundamental. It is a widely accepted truth that the professional competence and progress is greatly regulated by the quality of before service and during service training which the teacher gets in the shape of educational and professional development trainings.

\subsection{English language teaching in Pakistan}

English in Pakistan is utilized as an official and an important language. It is spoken and utilized by a generally little yet amazingly persuasive bit of nation's populace in the space of government organization, law, the military, the higher education, commerce and broad communications According to Paik (2018) the developing need and significance of English language at the present day has made the procurement of this language as a significant necessity for the present understudy. As English is seen as an irreplaceable apparatus as to make due in overall economy, the needs for English language have developed. In spite of the significance and need of English language, it has commonly been seen in the developing setting particularly in setting of Pakistan that individuals having fluent English effectively get section into higher establishments while such passage is denied to the individuals who have poor foundation in English language. The significance of English language is much increasingly exceptional after elementary level as this stage plans students either to be a winning part for the family through joining different exchanges or enter higher education institutes with better background. As Jimenez and Rose 
(2010) highlight this point that without a supported and efficient exertion, understudies during the time spent learning English have practically no desire for obtaining the sorts and measures of social and scholastic standard that they have to move into advanced education or important work. Thus, we can say that its importance can be observed by this fact that English language has been a confirmation of either an individual's success or failure in achievements

\subsection{Context of the study}

After the 1950s there has been incredible headway in correspondence because of which world has become global village. This brought forth need of regular language which was English. Nowadays English is called language of monetary framework, tourism, electronic data and advanced education. Understanding the need of the English language many professional development projects to train English language teachers have been initiated. Right now, government, in the coordinated effort with British Council, The Aga Khan University (ELT) projects and Different well reputed institutes such as Beacon house System and IBA to give proficient help to educators over the area. In Pakistan English language is taught in all Government, public and private-public schools. Among these, lies a huge chain of foundation-funded schools by different organizations and NGOs. One of the major issues in English language learning is cultural influence due to which a huge number of students are unable to learn language properly. Out of schoolchildren have been one of the biggest challenges for Sindh. In a recent report, about $40 \%$ children in province are deprived of education, which is estimated as 6.4 million. Different initiatives have been taken and many are still in working. However, to bring quality education for every child, different Educational foundations have been concentrating on endeavors for communities particularly those in the remote and lowincome background. The Context of the present study is those foundation schools, which are being run by Educational foundations in Sindh for students of under privileged backgrounds. In these schools, students and teachers both belong to rural areas of Sindh where quality education has always been questioned. In such context where well-educated and qualified teachers are rarely found, it has been observed that most of the teachers intend to choose teaching profession for these three common reasons:

- $\quad$ Financial Support

- $\quad$ Lack of other job opportunities

- To gain experience for other jobs

In such situation, teachers fail to bring better outcomes of students as their own capacity is low. To find quality teachers specifically, language teachers in such context becomes quite a challenging job. The only way to cope with such challenges is to train the existing available teachers through different training programs. Different organizations and educational foundations have been working for this purpose. This study thus investigates such teacher's professional development initiative by an educational foundation in free of cost foundation schools. The appointment of teaching associates is done by the educational foundation funded by Government of Sindh for English language teachers to enhance their knowledge, improvement in teaching practices, learning different language teaching methods and strategies and developing their teaching skills. The study is intended to investigate the effectiveness of in-service professional development of English language teachers in foundation schools

\subsection{Aims and objectives}

It has been observed that different Educational foundations and NGOs claim to run teacher education and training programs for teachers' capacity building and for academic development in schools. This study investigates:

- The perceptions of English language teachers towards effectiveness of in-service trainings by Teaching Associates.

- The perceptions of Teaching Associates regarding effectiveness of in-service professional development in foundation schools.

- The extent to which TAs have been successful in achieving objectives set for English language teaching by foundation

\subsection{Research questions:}

1. What are the perceptions of English language teachers towards effectiveness of in-service professional development by teaching associates in foundation schools?

2. What are the perceptions of TAs regarding effectiveness of in-service professional development of English language teachers?

3. To what extent Teaching Associates have been successful in achieving objectives set for English language teaching by foundation?

\section{Review of the literature}

For many years, teacher education has remained an important topic as many researchers have been working in this field. Instructors Education is a vast field that actually is associated with professional growth of the teachers, which 
shapes their overall teaching personality as well as enhance their teaching skills and increase their knowledge. It is further divided into pre service trainings and in-service trainings. A huge number of teachers in Pakistan receive pre service education through courses like Bachelors and Masters in Education programs, whereas in service education through trainings and professional development programs by either government or by different private organizations. Whether we talk about pre-service or in-service trainings, both have a separate importance level but regardless of how great pre-service preparing for educators is, it cannot be required to get ready instructors for all the difficulties they will look all through their professions. In-service trainings along these lines look to furnish teachers with open doors for in-service proficient improvement to keep up an elevated requirement of instructing and to hold a top-notch instructor workforce. As OECD's near survey on instructors noted (OECD, 2005). Teachers' education supports the improvement of showing abilities in instructors of different organizations. Many private or government institutes introduce such training programs for capacity building of teachers but unfortunately they either do not achieve their desired outcomes or teachers don't implement the learned techniques into their schools and hence all efforts and cost paid for the programs goes into vain. Many trainings and workshops for teachers are arranged where ESL teachers are being trained for English language teaching which include improving content knowledge, learning language skills, communication skills, designing students' maximum engagement activities and working according to varied levels of students. These trainings are being conducted putting efforts and energy and after hard work but what if these are not designed keeping the context and the level of ESL teachers and students in mind. Levin and Lockheed (1993) propose that developing nations, like, Pakistan, face issues in providing quality training to their young educated people and come up short on the most important assets including qualified teachers. (Government of Pakistan 1998), on the off chance that the nature of instructors who are the urgent piece of any training framework isn't great or up to the standard at that point to expect that nature of framework will be great is unreasonable. The low quality of the framework is disturbed in light of poor enlistment rehearses, untrained educators, and absence of spotlight on the expert advancement of the instructors in advanced education. A clear vision and effective steps from government side are still missing. While looking into the National educational policies, a clear negligence has been observed. Lack of professional skills and attitudes affects students learning outcomes and achievements. The most urgent factor for this disappointment is absence of political will and national vision, which have brought about deficient assets designation, poor administration and broken administration framework (Barbar 2010, DFID and USAID, 2006). Haq and Haq guarantee that 'Pakistan is the main nation in South Asia where open consumption on instruction as an extent of GNP has gone down since 199o. With growing need of time, teachers need to be trained in their respective domains specifically language teachers need to be trained for English language teaching. For this purpose, Government and Educational organizations need to design effective training programs for capacity building of teachers. There is not only a strong need of designing such effective professional development programs for teachers but also impact evaluation studies should be carried out to observe the effectiveness and importance of such programs. According to Owen and Rogger, "Effect assessment is predicated on the not outlandish view that residents everywhere should know whether projects are having any kind of effect". They attest that it is a right of citizens to realize that the cash that is being spent on these instructive projects is creating compelling intercessions and the program can meet its expected objectives and targets. They further recommend that evaluation is worried about deciding the range and degree of program results, deciding if the program is executed the manner in which it was expected or not and are the assets accommodated for the program utilized appropriately and astutely or not.

Junejo, Sarwar and Ahmed (2017) investigated Impact of an in-service training program. The participants in the study included the on duty teachers serving at Sindh Technical Education \& Vocational Training Authority (STEVTA), Government of Sindh. Data was collected through survey. Findings of the study revealed that the inservice training program had positive influence on the performance of teachers. The perceptions of teachers regarding their professional development were positive. It recommended that such in-service training programs should be introduced in subject areas along with general teaching trainings. Abdullah, Samupwa and Alzaidiyeen (2009) who investigated in-service training in public schools of Namibia carried out another study. The study selected 43 schools. The objectives of these trainings were to equip teachers with latest teaching methods, cooperative relationship between teachers and students, which will eventually help in improvement in results of students. It was revealed that the program failed to achieve the desired outcomes to the extent it was believed. Proper planning and implementation of in-service training program was recommended. STEPHEN ADU-DARKO (2013) also carried a study in which he assessed the effectiveness of an in-service training program by Atiwa District Directorate of Education Ghana. Participants of study were 168 teachers who attended teacher training. Data was collected using questionnaires and analyzed statistically. The influence of in-service training program on teachers' performance was positive. It improved improvement teaching methods, lecture delivery, class management, students' assessment techniques and cooperative relation between teacher and students. Overall improvement in teachers' performance was also observed. The study only recommended time management and provision of good material. 


\section{Methodology}

The present study followed mixed method exploratory design. This design consists of two distinct phases: Qualitative followed by quantitative, Creswell (2003). This process is also divided into two phases followed by data analysis. PHASE I involved semi-ructured interviews of 20 English language teachers conducted to investigate their views regarding their capacity building and satisfaction level on the part of teaching associates and semi structured interviews from 5 teaching associates were also conducted to investigate the perceptions of TAs regarding effectiveness of in-service professional development of English language teachers. PHASE II involved classroom observations of English language teachers (both male and females) in foundation schools. 20 schools were selected through convenience sampling, who have been receiving trainings by teaching associates. While selecting schools it was ensured that the selected schools represent the whole population.

\subsection{Data collection}

The study used semi-structured interviews and observations as data collection tools. In phase I, semi-structured interviews were conducted for recording views and perceptions of Teaching Associates as English specialists $(\mathrm{n}=5)$ and Language teachers $(n=20)$ about effectiveness of in-service professional development. In second phase, observations of $(\mathrm{n}=20)$ language teachers were conducted. For observation, a checklist was used to record the data. A schedule was set for class observations of teachers to get required data regarding implementation of received training and support by teaching associates. In order to collect data, the researcher field visited the foundation primary and elementary schools, which are mostly located in rural areas of Sindh.

\subsection{Participants}

Participants of the study are $(\mathrm{n}=20)$ English language teachers from foundation schools in Sindh under trainings of teaching associates and $(\mathrm{n}=5)$ teaching associates as major stakeholders.

\subsection{Data analysis}

In first phase, semi-structured interviews of $(n=5)$ teaching associates and (20) language teachers were analyzed through thematic analysis by codifying the data and recording repeated themes in responses. In second phase, the results obtained from observations were analyzed through SPSS version 26. Statistical data is represented in frequency tables, bar and pie charts. The consistency and validity of the checklist was measured through reliability (Carmines \& Zeller, 1997). Cronbach's alpha test was used to calculate the reliability that was .739 with 36 numbers of items.

\section{Findings and discussion}

\subsection{Phase I:}

According to Adu Darko (2013), The most important purpose of in-service training is to improve the performance and practices of teachers. In the study conducted by him, $96 \%$ teachers were observed improving their instructional planning skills. In the light of this, the findings from my study revealed that most of the teachers' perceptions agreed that they were supported by the weekly training sessions in proper instructional planning of English language lessons through development of weekly and daily planners. They try to plan their lessons consisting of different interactive activities that help students to learn language in fun ways. Ashrafuzzaman (2018) states that the perceptions of teachers in his study revealed that making lesson plans before delivering lesson helped in proper instruction. Whereas teachers were not using activities gave different reasons. According to them, as the school was funded by foundation there is lack of material due to which they cannot design or use activities in language classrooms. They also learnt to assess the knowledge of students in formatively to gauge the learning outcomes of students.

Teachers also believed that through weekly sessions they got awareness about the usage of Audiovisual devices for integrating language lessons with advance learning e.g. using recorded stories, video lessons, activities and pictures for picture comprehension. To support the response, in the study conducted by Ashrafuzzaman (2018), the participants shared that before training they only gave instructions and taught traditionally through books and posters sometimes but the training helped them to use Audiovisual devices such as Audio ipod games, posters and charts. They shared that Audio has helped them to work on listening practices of student. Few teachers believed that the weekly training sessions help them to enhance their own knowledge and skills through micro teaching classes arranged by TA. They also give presentations, which are source of knowledge and motivation for them. They try to use English language in the classes now. Ashrafuzzaman (2018) stated about the perceptions of his participants that in-service training sessions motivated them to use English language in the classes because they had to use English during sessions for reflection.

Teachers were asked to give their perceptions regarding the change they feel after the intervention of Teaching Associates. Adu Darko (2013) revealed in his study that, about 95\% responses of participants agreed that the inservice training has improved their teaching methods and delivery. In reference to this, most of the teachers in this 
study were of the opinion that the intervention of TAs as English language specialists has put a positive effect on teaching methods. Language classes are more formal in those schools. Rather than book and board only, they are using different teaching methods. They have been using traditional methods to teach language through GTM and rote learning but they are trying to implement activity based leaning in the classes where they plan interactive language activities e.g. THINK-PAIR-SHARE, jigsaw, grammar activities) which are helpful in clearing grammatical concepts of students. Not only have this but their concepts about different grammar topics been cleared.

One of the important factors in instructional planning is scheme of studies. It is basically a plan that consists of a breakdown of units or lessons to be covered in particular week, month or session of a class. It also consists of time allocated for each lesson or topic, related strategies, methods and techniques. As Okai (2010) states that scheme of studies is a plan of work which portrays the substance and learning encounters that ought to be treated each term of the academic year. Teachers shared that they have got awareness about developing and using scheme of studies for English subject planning.

Regarding their perceptions of learning from model classes, almost all participants believed that they have been observing Teaching Associates in model classes. They were learning to motivate the students who are less attentive to learning English language. As Asrafuzzaman (2018) revealed in his study that the in-service trainings increased motivation level of teachers which contributed in students motivation further. In the present study, Teachers also shared that the Teaching associate follow an effective way of teaching in three phases which inspire them and they learn to anticipate students before beginning a topic to grab attention of the students, they deliver the lecture which leads to effective ways of concluding class and assessing students learning before they leave class. Students need to be motivated and prepared to learn a new thing and to grab their attention a teacher should make the start as interesting as he can. As participants in the study conducted by Ashrafuzzaman (2018) gave their perceptions that after attending the trainings they used warm-up activities, sounds and pictures to make learning interesting from the beginning and asked questions in the end from the text.

Most of the participants believed that through model classes by Teaching Associates, they have learned assessing students in language classes through formative techniques. Formative assessment is basically an ongoing way of assessing students' knowledge during a class or a session in order to gauge their learning outcomes. These outcomes help teachers to assess their instruction as well as to see whether their strategies or methods are effective or not. This helps in further planning of instruction. Black and William (1998) state that endeavors to improve educators' formative assessment capacities do in fact lead to critical learning gains.

While giving their perceptions regarding their professional development through classroom observations and feedback by Teaching Associates, most of the participants believed that their classes are observed and after classes Teaching associates share the observed points as feedback to highlight their improvement areas and weaknesses. These include their incorrect usage of English language words or sentence structures, ineffective use of any strategy, or lack of proper planning and much more. While few teachers gave their perception that they receive feedback weekly this should be on daily basis. In this way they would be able to make corrections on time and improve quickly. Secondly there should be a proper record of observed points in school as well. For good performance, a good level of motivation and encouragement is always needed.

Teachers shared that they receive encouragement as well as suggestions to improve their language teaching practices. One of the major issues faced by schools throughout the Sindh is poor subject knowledge of teachers. It not only creates trouble for that teacher but it affects students' learning and achievements. Participants agreed to the point that with support of TAs they are working on improving their subject knowledge and preparing themselves to deliver effectively in language classes. Not only was this but they preparing for their own learning.

RQ2: What are the perceptions of TAs regarding effectiveness of in-service professional development sessions in English language classrooms?

The findings of the data obtained from Teaching Associates revealed about different challenges faced by them during professional development of language teachers. Most of the Teaching associates shared that initially the basics of students in English language were very low which was challenging for them. According to a Teaching Associate it is difficult to build knowledge of a $5^{\text {th }}$ grader when he can hardly utter words of target language or write a simple sentence. It took a great deal of time to build some knowledge of English language. A rarely discussed challenge like child labor was also shared by Teaching Associates. Due to poverty parents engage children in work to support family which is a heart breaking factor to know. Students work in fields and shops to support the family after school therefore, they cannot pay proper attention to learning. It also perceived by Teaching associate that poor language skills of students also come under major challenges in foundation schools. Speaking is an advance skill for them but students even lack basic reading and writing skills. Language barrier was indented as another challenge faced in language classrooms. Language teachers and students with different linguistic backgrounds also face difficulty in communication in a context where English language is taught through translation in mother tongue as a second option. Hence Teaching Associates also faced this problem. Teaching associates also highlighted few factors that affect English language teaching and learning process. According to 
their perceptions, diverse linguistic background of students is a factor that affects ELT and learning. Another factor was low capacity of language teachers. They are not well prepared to instruct in language classrooms. We have always discussed different issues regarding hindrances in language teaching but a rare factor been discussed is Religious factor. Teaching Associates perceived this fact that religious factors do affect language teaching and learning. One of the Teaching associates highlighted this factor by responding that foundation schools are mostly in rural areas and in no income background. A good number of schools are working effectively and even the communities are willing to send their children to lean language but on the same time it has been observed in a community that they did not want their children to learn a foreign language because they think it belongs to yahuds. It is not a language of Muslims. So, assumptions regarding religious affects are being attached with English language learning. Teaching associates shared that students in rural areas are habitual of learning language through translation from word to sentence level. The students speak mother tongue all the time in school as well as during language class. Secondly teachers also use traditional methods of language teaching based on translation rather than adopting activity based learning which is an effective way of integrating language in the classrooms. A variation in perceptions of Teaching Associates was observed. Ahmed (2011) argues that with the absence of training support, instructors can't progress in a proper and dynamic way and result in the losing to the degree that they accept or adopt the focal point of student. According to the Teaching Associates, untrained teachers cannot deliver the lecture properly. Training helps a teacher to develop his skills as an effective teacher. Through training, individual gains knowledge about strategies to handle issues related to language learning and class management. It equips a teacher with expertise and skills. A lack of training can either slowdown the learning process or make it ineffective. Teaching Associates also conduct classroom observations of teachers to evaluate their performance in language classes and provide feedback to the teachers.

According to O'Leary (2012), classroom observations are used in education to assess the effectiveness of performance and teaching practices of a teacher. While one might identify variations in the methods used in educational systems across the globe, one of base issues that negotiate through different backgrounds and motives behind classroom observation in schools is the idea of effectiveness of teacher. The effectiveness of observation also depends on the criteria and the tools used for the purpose. Teaching Associates shared that they either observe teachers for certain indicators or through evaluation forms provided by foundation and prepared by trainers. Those indicators are shared prior to the observation so that teacher understands it and try to implement the things properly. After observation they share feedback with teachers. According to them feedback helps teachers to identify their improvement areas to work on and they get to know about their weak point in language teaching. When the teachers improve their identified areas, their knowledge about subject increases which leads to confidence in classrooms.

While presenting their views regarding the effects of model classes in language classes, the Teaching Associates highlighted few positive changes by language teachers. According to them, when language teacher observes the teaching practices of Teaching Associates, their concepts regarding the observed topics get cleared. The teachers not only like ideas and activities by Teaching Associates but also try to recreate them and design their own for implementing in their classrooms. Öztürk (2018) conducted a study regarding effectiveness of in-service professional development. He revealed that the participants of his study implemented the activities done in training session in their own classrooms and the teachers found that it was easy to implement the learned activities from training session in their classrooms because those activities were experienced. They felt confident to use them. According to the perceptions of teachers, they used lecture method previously whereas when they did activities in the classrooms they found them successful. Teaching Associates revealed that teachers now try to work on concepts rather than rote learning. Teachers try to implement activity based learning in their classrooms. Some perceptions were against this idea. As Teaching Associates shared that many teachers seemed to be reluctant to accept the feedback. These teachers have been teaching without any proper planning for many years. They only use book and board method which does not require much hard work like that in the planning. It took a great deal of time to convince them for planning effectively and use different interactive activities in the classroom. Now they try to implement activity based learning for language instruction somehow. According to the views of Teaching Associates, One of the reasons behind no activities was that the foundation schools run on funds. There are times when the school lacks basic stationary even. The teachers gave this reason for not implementing activities in language classrooms. The Teaching associates then helped them to work with minimum available resources and low cost material. As Ogwezi and Wolomsky (1985) state that situations for fruitful learning improve when a teacher uses strong materials from setting to help or portray what he teaches.

According to the Teaching Associates, weekly sessions also have been contributing to the change in language classrooms. According to them teachers have been learning about different language teaching strategies which are interactive and helps students to learn effectively. Activities like Reading comprehension, think aloud, jigsaw, Think-pair and share, picture comprehension and picture prompt etc can enhance the overall performance of second language learner. Through sessions language teachers are keen to improve their content knowledge. Teaching Associates shared an interesting factor that few other subject teachers also seemed to take interest in weekly training sessions. Those teachers were having English language learning courses for improvement in 
language. They attend sessions to learn and improve their language skills as well. Lesson planning is the most important step before entering the classrooms. Richards (1998) states about the significance of lesson planning that effectiveness of a lesson conducted depend on the effectiveness of the lesson plan. The more effort is put into planning of a lesson, the more successfully lesson is conducted in the classroom. From the responses by Teaching Associates, the implementation of training sessions is observed by them through pre and posttests, classroom observations and surprise visits.

\subsubsection{PHASE II}

As Robinson (2002) states about significance of observation that whatever an individual does may be different from whatever he says, and observation provides what it actually is being done. In phase I, interviews of both; trainers which are Teaching Associates and trainees who are receiving in-service professional development trainings were conducted. The purpose behind the interviews was to know the perceptions of language teachers in foundation schools and perceptions of Teaching Associates regarding effectiveness of in-service professional development. To observe whether the things are implemented the way they were intended to or not. For this purpose a checklist was used consisting of different categories each having different indicators. After conducting the observation, data was analyzed through SPSS version 26. The reliability of the data was checked trough Chronbach's Alpha test. Discussing the results below:

\section{i. INSTRUCTIONAL PLANNING:}

According to results of observations, Instructional planning was the second highest implemented factor in the language classrooms. In this category, 50\% participants had fully developed and maintained lesson plans for English. About 15\% participants had better lesson plans than those $10 \%$ participants who were trying well to implement lesson planning but not up to the mark. $20 \%$ participants had poor lesson planning because of lack of knowledge about instructional planning, whereas 20\% participants do not develop lesson plan. Among those participants certain views were also observed that 'I do not develop lesson plans because everything related to the topics is in my mind and I know what to do every da. I find lesson planning difficult and it takes lot of time.' Those teachers have been teaching traditionally with no pre planned activities or methods. From 20 participants, $50 \%$ participants had fully developed lessons according to Scheme of studies for English subject where as $20 \%$ participants had no knowledge about scheme of studies. Rest of the participants had less of poor knowledge about scheme of studies and its usage. $45 \%$ participants had well developed one go lesson plans for each day and50\% participants had teacher daily diaries where they maintain details about instruction. While teacher observations it was noted that $45 \%$ language teachers had good knowledge of the content they were teaching and $20 \%$ teachers had average knowledge about content. The participants having good content knowledge were aware of the grammar topics and language practices in classrooms. 25\% language teachers had no content knowledge and about same ration of language teachers had poor content knowledge. This seemed to be a result of another observed factor which was no relevant qualification. Few language teachers had not even a background or degree related to the subject they were teaching. There were economic students, BA and even intermediate teachers. A worldwide overview of essential English language instructors from 89 nations found that in $21 \%$ of the cases the educators referenced that they were not qualified explicitly to instruct English (Emery, 2012). Another reason observed might be lack of other career opportunities. Teachers choose to join teaching profession for fulfilling the needs of their families or for their own financial support. Oplatka (2007) revealed that family assumed a key role in the decision of female Pakistani instructors to join teaching profession. So, it can be observed that financial and social issues do affect language learning as teachers do not have relevant subject knowledge. Student learning outcomes are important part of instruction. Until and unless a teacher is not aware of what he wants his students to gain and what he should work on, he could not do it effectively. Students' learning outcomes are basically a set of statements that indicate skills; knowledge and learning that a student needs to possess and gain at the completion of a topic. Unfortunately, many teachers do not even know what it actually means. The only goal for most of the language teachers is to complete the course work and conduct exams. Teachers rarely pay attention to the fruitful results for students. During observations, 55\% language teachers were well aware of SLOs, 15\% language teachers had somehow knowledge about SLOs because those are mentioned on the top of the page for every topic and about $20 \%$ teachers had no knowledge about SLOs and how to achieve them by proper planning. Teaching methods do contribute to effectiveness of instruction. Having no knowledge about teaching methods can lead to ineffective teaching and hence no desired results can be obtained. Many teachers apply same method for each lesson. The teacher reads the lesson followed by reading by students and then written work. About $60 \%$ language teachers were aware about teaching method related to the topic they were teaching. They implemented the methods which were taught to them during weekly sessions. $20 \%$ implement it somehow and about $10 \%$ do not implement methods nor have any knowledge about methods.

\section{ii. PROPER LECTURE DELIVERY:}

Effective lecture delivery consists of various factors to be followed from beginning to end. An effective teacher always knows about teaching objectives. He enters class with clear objectives and strategies related to the class. During the observations first indicator that was considered was statement of awareness of objectives and strategies 
and mentioning them on the board. 55\% language teachers implemented this by stating related objectives, SLOs and strategy on the board. $25 \%$ language teachers did not implement this component in the classroom while rest of the participants either stated the strategy or topic only. Research proves that brainstorming is an amazing instructing procedure to produce thoughts on a given point. It advances thinking aptitudes. At the point when students are solicited to think from everything identified with an idea, they are truly being approached to extend their reasoning abilities. Usually, a kid with exceptional needs will say they don't know. But with the method of brainstorming, the kid says what strikes in his mind related to the topic. Brainstorming advances accomplishment for students with exceptional needs as there is no concept of wrong or right answer. It is about participation. Brainstorming helps a teacher to know about prior knowledge of students as well as it recaps the things that were previously learned. While instruction, 55\% teachers fully implemented this technique. $20 \%$ teachers performed well. Use of this technique by $10 \%$ teachers was implemented somewhat while $15 \%$ did not use this technique at all. They directly started teaching about the topic. The students seemed less motivated and interested. A child can best learn through a situation which is familiar and easy for him. Language learning is a tough job for such kids who never have any exposure to English language. It might take time to learn. Setting a situation for such students by using their own culture, background and context can help him to learn in an effective way. In language classrooms, $40 \%$ teachers seemed to implement this technique fully whereas $20 \%$ teachers did not implement it. They were unable to connect language learning with students' backgrounds and experiences. A learner needs motivation and a sense of importance. Usually in traditional classrooms teachers accept correct responses and on wrong responses demotivate students. To make sure that students don't get demotivated, teachers should accept all the responses without saying 'You are wrong or even that you are not right' and later correct them. 55\% teachers fully implemented the practice of recording students' responses on board and make them visible to students. Without pointing at an incorrect response they helped students to learn by clearing their concepts. Few teachers somehow implemented it and about 25 teachers did not record responses on board neither accept them. Writing is an important skill to focus while language teaching. Nearly $50 \%$ teachers had either activities for writing exposure in the plans or they actually were implementing it through short answers, sentence making and in higher grades paragraph writing as well. Few teachers' tried it to implement to some extent while rest of $25 \%$ didn't implement it neither had any planning regarding it. teachers don't give appropriate writing exposure to language learners to empower them utilize their imagination and thoughts while figuring out how to write includes figuring out how to utilize language in a specific setting (Emmitt et al, 2003). In rural areas language learning is not less than a challenge especially when there is less or no usage of target language in the schools. In such backgrounds language is taught through grammar translation method mostly. Siddiqui (2010) states that English is typically instructed by those instructors who don't have competency in English language and these instructors teach language through translation technique, the method by which they were instructed. While observation $45 \%$ language teachers fully implemented other methods than GTM like direct method, interactive groups, language practice through role plays and small presentations. $10 \%$ teachers where unsuccessful to implement whereas $35 \%$ teachers were using GTM only. According to them the kids had poor knowledge of language and their basics are weak due to which they do not understand English language nor can speak unless they translate it for them. In majority of schools in rural areas thee is less concept of activity based learning. Teachers remain active all the time giving lecture while students listen passively. This practice does not allow students to share their needs and ideas. Students do what a teacher asks to do. They rarely use reasoning and questioning. As Nikolov (1999) states that students are motivated to learn a language if they have access to three things: engaging and interesting material, creative activities and a supportive and cooperative teacher. Any language can be learned with interest and through ongoing practice. For this purpose a language teacher needs to design such activities that allow learners to practice language skills regularly. $60 \%$ language teachers were observed implementing activity based learning fully in the language classrooms. $15 \%$ teachers tried to implement well. $10 \%$ teachers couldn't implement properly and rest of the $15 \%$ was not implementing activity based learning in the classrooms. It was observed that $45 \%$ teachers actually plan and implement activities that cover four language skills where as $25 \%$ do not plan or engage students in such activities for practicing language skills. Few teachers give this reason that the classes in foundation schools are overcrowded due to which they feel difficulty to plan or use activities in the class .Grouping and pairing strategies help students to interact and learn from each other. Students get a chance to get engaged into activities which they avoid performing individually. 50\% language teachers were observed using grouping or pairing strategies. Few teachers couldn't use this strategy properly and 25\% language teachers did not implement this strategy.

iii. USAGE OF INSTRUCTIONAL MATERIAL

Lockheed (1991) states that instructional materials are basic ingredients in learning and that the educational plan couldn't be properly executed without them. Observations revealed that $45 \%$ language teachers all relevant instructional material ready and $45 \%$ did not have relevant supportive material. Rest of the $10 \%$ had some of the material ready. Relevant supportive material helps a teacher to properly and effectively implement the things. Language can be best taught with the help of instructional material which is used in activities. It not only helps students' learning but teachers also become confident and work effectively. As Kochhar (1991) puts in that an 
instructor who has satisfactory and pertinent facilities is progressively certain, viable and gainful. It is not about availability only. There have been schools where supportive material was present but less usage or no proper usage was observed. 50\% language teachers from overall observed, implemented the proper usage of instructional supportive material where as 35\% didn't use any material other than book and board. $10 \%$ teachers tried to use the material to some extent.

\section{iv. CONCEPTUAL CLARITY}

Conceptual clarity means to understand the concept of a particular topic. In traditional language classes teachers mostly pay more attention to rote learning than to help the students understand the in-depth concept of a topic. During my observation one of the participants was teaching about application writing. I observed that the teacher wanted the children to memorize application writing. Rather than making this clear that how application is written, what do call an opening, the body and the closing, teacher focused on the purpose only. 50\% teachers were observed paying attention towards conceptual clarity by giving real life examples. $15 \%$ somewhat tried and $15 \%$ teachers were not successful to clear the concepts of the students. About 20\% language teachers didn't implement conceptual clarity in the language classes. Teachers' attention, engagement of students and timely feedback also helps in conceptual clarity. In this regard, $50 \%$ teachers were observed to implement fully and $20 \%$ teachers were not performing in this regard. In a context where students learn a foreign language, possibility is that they can make mistakes and get wrong concept of a grammar component. To help students in this aspect teachers need to check periodically and help them correct on time. Half of the participants seemed to implement this practice, few somewhat implemented, and 15\% teachers did not bother to check and correct.

\section{v. INTEGRATION OF LANGUAGE IN CLASSROOM:}

The schools in rural areas face a major problem which is usage of target language in the classrooms. Research reveals that most of time language teacher is found either translating the material for students or reading loud with translation and students repeat the same. Since teachers do not use English language in the class and utilize time in only translating and reading, no other language development activities are done in class. Translation and maximum usage of mother tongue hinders the practice of English language skills. It does not mean that one has to put aside his own language but at least teachers can make sure that they themselves use the language and help students to use that too. Positive reinforcement can help in this regard. In selected foundation schools, it was pleasant to observe that $45 \%$ language teachers were facilitating students to use English language. About 20\% teachers implemented well where as $15 \%$ teachers averagely facilitated students to use target language. Unfortunately, 20\% teachers do not implement this at all. Students use language when they observe their teachers doing so. Many teachers don't use English language in class nor use it for instructions given to students. However 45- 50\% teachers from observed participants use language in class for instructions also. They used simple sentences according to the understanding of students. $45 \%$ teachers used board to introduce new words making them visible to the students and about $60 \%$ teachers emphasized on key vocabulary in the lesson which is helpful for students to understand the content and clear concepts.

\section{vi. ERROR ANALYSIS AND ERROR CORRECTION:}

As indicated by Ogwezi and Wolomsky (1985) that the instructor improve conditions for productive learning when he encourages the learners to get awareness about their errors and weaknesses in the learning procedure. It helps learner to gain self-confidence and increase understanding about the things. 60\% language teachers from the selected ones implemented error analysis and error correction. Teacher analyzes student's error and makes immediate correction in written or spoken language by students. Rest of the language teachers either don't implement it or do not implement it effectively. Slope and Flynn (2006) propose that the most ideal approach to provide error correction when learners make grammatical or pronunciation is basically to demonstrate the right English without clearly pointing out the blunder. $60 \%$ teachers were observed helping students to correct pronunciation of words while reading. $10 \%$ language teachers seemed to implement it averagely and $10 \%$ teachers couldn't implement it as they themselves face issues in pronunciation of English words. 20\% teachers did not implement it all. In my views, this might be the reason behind students poor pronunciation that teachers do not correct it on spot or they themselves have less or no knowledge about pronunciation of words.

vii. CONSOLIDATION:

Brown and Abeywickrama (2010) describe assessment as an ongoing procedure that consists of different strategies to gain knowledge about student's learning by orally or written forms. Mihai (2010) affirmed that Assessment is substantially more than tests and test scores. It is a blend of a wide range of formal and casual decisions and results happening inside and outside a classroom. Assessment basically deals with checking students' learning in an ongoing session or at the end of the session. There are many types of assessment but three main types are popular in education: formative assessment, diagnostic assessment and summative assessment. In terms of purpose of assessment, it can be formative if the teacher intends to gain knowledge about attitudes, behavior, learning and effectiveness of his teaching practices. This type of assessment not only helps teacher to know to which extent a learner has gained or which strategy or method goes successful but also helps him to identify his own mistakes, improvement areas and effectiveness. Diagnostic assessment is done to deal with a particular problem related to 
teaching and learning or to know about in-depth reasons behind a issue in learning. The purpose of summative assessment is to measure students' learning outcomes at the end of a session or academic year and to assign the grades. While observations a good number of language teachers were observed assessing students formatively by asking content specific questions to gauge whether outcomes are achieved or not. 55\% teachers not only asked questions but also summarized the points at the end of the class. Whereas, rest of the teachers either do not implement at all or to lower extent. Majority of teachers gave home tasks as well.

CONCLUSION AND RECOMMENDATIONS: Khan (2010) states that instructors should be given training before entering teaching profession as well as in particular during instruction too on the grounds that instructors' expert improvement is viewed as a ceaseless facilitation procedure that updates and overhauls educators' information to continue with instructive changes. The study revealed different facts about the effectiveness of inservice professional development by Teaching Associates in foundation schools. The perceptions of language teachers and Teaching Associates regarding in-service professional development directed towards observations, which revealed the following facts that, the implementation of in-service professional development. The Initiative of in-service professional development has been found effective for language teachers in following aspects. The results show that the Teachers have been benefited by training and feedback along with model classes which helped them to learn different ways of assessing students' knowledge to gauge the learning outcomes of the learners. The highest implemented component by language teachers in language classes was consolidation and assessment. It shows that most of the language teachers are following the consolidation and assessment methods and strategies. This has helped them to use assessment to improve the language skills of students as well as assess their own teaching skills, strategies and practices. Second highest component to be implemented was Instructional planning which consists of lesson planning, maintenance of teachers' diary, one go lesson plans and Awareness of student learning outcomes. The teachers shared that they never had implemented instructional planning and found it difficult but through the continuous support of Teaching Associates they are now trying to implement it. Third most implemented factor was error analysis and error correction (4.1 mean). Until and unless a teacher does not analyze the language errors of students and make immediate corrections through constructive feedback, the student can never progress in language learning. Forth most implemented component been observed was proper lecture delivery in language classroom (3.8 mean). Proper use of instructional material was fifth most implemented component ( 2.5 mean). The least implement components by language teachers in English language class were integration of English language in classroom (3.3 mean) and conceptual clarity (2.2 mean). Hence, this makes sense that intervention of Teaching Associates in foundation schools has put positive effects on capacity building of language teachers.

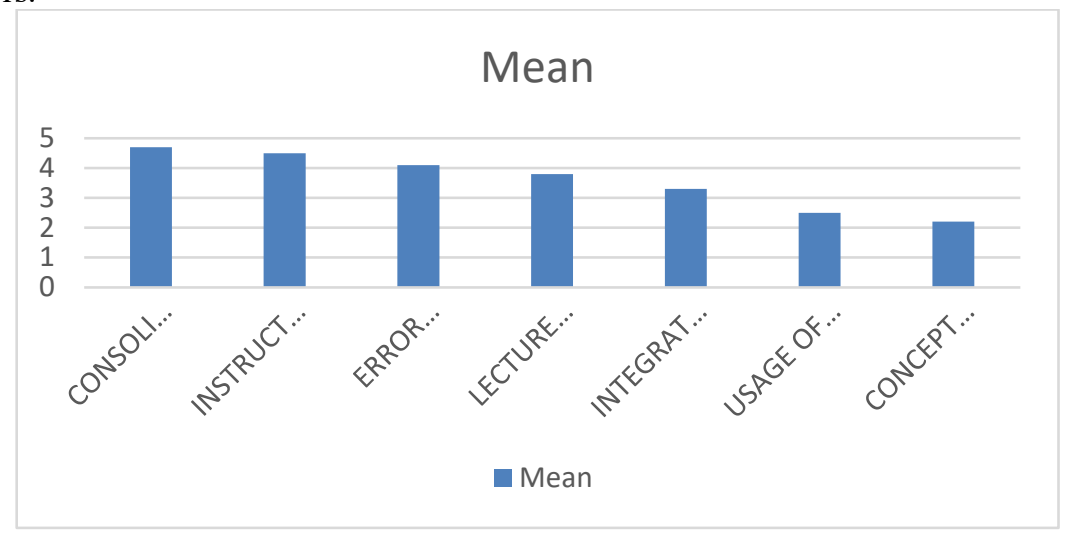

\section{RECOMMENDATIONS:}

Recommendations for proper planning for training session were given Teaching Associates are suggested to pay more attention towards Integration of English language in the classrooms for which teacher needs to be equipped with such effective methods and strategies by which they will be able to design activities that maximize Language usage in classrooms and minimize traditional translation methods. Language teachers need to use language in classes because students imitate teachers. Secondly maximum usage of instructional material should be implemented. Students learn a language properly when they find interesting activities and relevant supportive material. TAs need to pay more attention towards usage of different methods in training to make it more effective. However, usage of different methods of training rather than a monthly, six months trainings or yearly training have put a positive effect on teachers under training as this whole cycle maximize the work and efforts at the side of TAs and teachers get more time for guidance and help from TAs. In the study conducted by Junejo, Sarwar and Ahmed (2017) they investigated Impact of an in-service training program where they found that both theoretical and practical methods of teaching were used. The discoveries affirm a few examinations (Boer, 2007; Learning Point Associates, 2010; Fenwick, 2001) on teacher training that additionally distinguished numerous employments 
of strategies to achieve training objectives. In that study, it was observed that the TAs used different approaches and methods in training ie. Weekly workshops, model teaching and observations which fall in theoretical as well as practical methods. Junejo, Sarwar and Ahmed in the case study in STEVTA Karachi support the idea that new teaching concepts should be initiated to make such in-service training programs more effective like training methods and strategies. Therefore, it is suggested that in-service teacher training suppliers should keep on presenting diversity in training activities with various viewpoints regarding teaching. It will help the instructors, especially vocational educators, to accomplish new skills and strategies and along these lines improve the nature of professional training in Pakistan. On the other hand, Productivity was observed in classes where instructional material was used to engage students and increase their motivation. Teaching Associates are also recommended to pay attention towards capacity building of language teachers in aspect of conceptual clarity of students. Rather than directly instructing language and allow rote learning of grammar topics where students are forced to memorize the rules and structures. Teachers need to be aware about techniques to clear concepts of students that they usually find tough.

\section{REFERENCES:}

1. Alimorad, Z., \& Tajgozari, M. (2016). A Comparison of Iranian High School Teachers' and Students' Perceptions of Effective English Teachers. SAGE Open, 6(4), 2158244016679212.

2. Ashrafuzzaman, M. (2018). Impact of in-service training on English teachers classroom practice at primary level. Journal of Language and Linguistic Studies, 14(3), 77-103.

3. Ashraf, D., Ali, T., \& Hosain, A. (2014). Youth development and education in Pakistan: Exploring the relationship.

4. Boyle, B., Lamprianou, I., \& Boyle, T. (2005). A longitudinal study of teacher change: What makes professional development effective? Report of the second year of the study. School effectiveness and school improvement, 16(1), 1-27.

5. Boyatzis, R. E. (1998). Transforming qualitative information: Thematic analysis and code development. sage.

6. Day, C., \& Sachs, J. (2004). International handbook on the continuing professional development of teachers. Maidenhead: Open University Press.

7. Dilshad, R. M. (2010). Assessing Quality of Teacher Education: A Student Perspective. Pakistan Journal of social sciences (PJSS), 30(1).

8. Effective Teacher Professional Development. (n.d.). Retrieved from https://learningpolicyinstitute.org/product/effective-teacher-professional-development-report

9. Garet, M. S., Porter, A. C., Desimone, L., Birman, B. F., \& Yoon, K. S. (2001). What makes professional development effective? Results from a national sample of teachers. American educational research journal, 38(4), 915-945.

10. Giraldo, F. (2014). The impact of a professional development program on English language teachers' classroom performance. Profile Issues in TeachersProfessional Development, 16(1), 63-76.

11. Hilda, B. (2014). Professional Development and Teacher Learning: Mapping the Terrain: University of Colorado, and Boulder. Aga Khan University, Institute for Educational Development, Karachi.

12. Hoodbhoy, P. (Ed.). (1998). Education and the state: Fifty years of Pakistan (Vol. 50). Oxford University Press, USA.

13. Ivankova, N. V., Creswell, J. W., \& Stick, S. L. (2006). Using mixed-methods sequential explanatory design: From theory to practice. Field methods, 18(1), 3-20.

14. James, P. (2001). Teachers in Action. Tasks for in-service language teacher education and development. Ernst Klett Sprachen.

15. Junejo, M. I., Sarwar, S., \& Ahmed, R. R. (2018). Impact of In-Service Training on Performance of Teachers A Case of STEVTA Karachi Region. International Journal of Experiential Learning \& Case Studies, 2(2), 50-60.

16. Koç, E. M. (2016). A General Investigation of the In-Service Training of English Language Teachers at Elementary Schools in Turkey. International electronic journal of elementary education, 8(3), 455-466.

17. Mavidou, A., \& Kakana, D. (2019). Teachers' Experiences of a Professional Development Program for Differentiated Instruction. Creative Education, 10(3), 555-569.

18. Nawab, A. (2012). Is it the way to teach language the way we teach language? English language teaching in rural Pakistan. Academic research international, 2(2), 696.

19. Nunan, D., \& Carter, R. (Eds.). (2001). The Cambridge guide to teaching English to speakers of other languages. Ernst Klett Sprachen.

20. Osamwonyi, E. F. (2016). In-Service Education of Teachers: Overview, Problems and the Way Forward. Journal of Education and Practice, 7(26), 83-87.

21. Öztürk, M. (2019). An Evaluation of an Innovative In-Service Teacher Training Model in Turkey. International Journal of Higher Education, 8(1), 23-36. 
22. Retallick, J., \& Mithani, S. (2003). The impact of a professional development program: A study from Pakistan. Journal of In-service Education, 29(3), 405-422.

23. Téllez, K., \& Manthey, G. (2015). Teachers' perceptions of effective school-wide programs and strategies for English language learners. Learning Environments Research, 18(1), 111-127.

24. Villegas-Reimers, E. (2003). Teacher professional development: an international review of the literature. Paris: International Institute for Educational Planning.

25. Mohanty, S. P. (2014). In-Service Training at Elementary School Level: Impact on Classroom Practices. Learning Community-An International Journal of Educational and Social Development, 5(1), 3342. In-Service Training at Elementary School Level: Impact on Classroom Practices Sankar Prasad Mohanty $1 *$ 